\title{
IPHONE APP USE TO COBB ANGLE IN ADOLESCENT IDIOPATHIC SCOLIOSIS: DOES THIS APPLY?
}

\author{
USO DE APLICATIVO DE IPHONE PARA ÂNGULO DE COBB NA ESCOLIOSE IDIOPÁTICA \\ DO ADOLESCENTE: É APLICÁVEL?
}

\author{
USO DE APLICACIONES MÓVILES PARA IPHONE PARA EL ÁNGULO DE COBB EN LA \\ ESCOLIOSIS IDIOPATTICA DEL ADOLESCENTE: ¿ES APLICABLE?
} Antenor Rafael de Oliveira Mazzuia ${ }^{1}$, Diógenes Rodrigues Machado ${ }^{1}$, Denis Kiyoshi Fukumothi ${ }^{1}$, Luccas Franco Bettencourt Nunes ${ }^{1}$,
Carlos Tucci Neto ${ }^{1}$, Henrique Menucci de Haidar Jorge ${ }^{1}$, Rafael Tormin Ortiz ${ }^{1}$, Carlos Augusto de Mattos ${ }^{1}$

\begin{abstract}
Objective: To validate a new method of measuring the Cobb angle for scoliosis from the mobile app CobbMeter to facilitate the evaluation and measurement in clinical practice. Methods: Five observers with minimum experience of two years in the field performed radiographic measurements of Cobb angle in 24 radiographs of patients with adolescent idiopathic scoliosis through the CobbMeter. Observers performed serial measures on the images with the application, which were repeated after one month. The most experienced appraiser of the group, after measurements were made through the application, determined the Cobb angle in each radiography by the traditional method. Results: The mean standard deviation by comparing the angles electronically and manually measured had no clinical significance. Although $40 \%$ of electronic measurements are outside the confidence interval when compared to manual measurements, this difference was insignificant in clinical practice. Conclusions: The CobbMeter is another alternative for measuring Cobb angle in scoliosis.
\end{abstract}

Keywords: Scoliosis/diagnosis; Spine/abnormalities; Software validation; Mobile applications.

\section{RESUMO}

Objetivo: Validar um novo método de medida do ângulo de Cobb para escoliose a partir do aplicativo para aparelho telefônico celular CobbMeter para facilitar a avaliação e medição na prática clínica. Métodos: Cinco observadores com experiência mínima de dois anos na área realizaram medições radiográficas do ângulo em 24 radiografias de pacientes com escoliose idiopática do adolescente com o CobbMeter. Os obsenadores realizaram medidas em série nas imagens com o aplicativo, as quais foram repetidas após um mês. O avaliador mais experiente do grupo, após as medições feitas com o aplicativo, determinou em cada radiografia o ângulo pelo modo tradicional. Resultados: A média do desvio padrão na comparação dos ângulos medidos eletrônica e manualmente não foi clinicamente significativa. Apesar de 40\% das medições eletrônicas estarem fora do intervalo de confiança ao serem comparadas às medições manuais, essa diferença se mostrou insignificante na prática clínica. Conclusões: O CobbMeter é mais uma alternativa para a medição do ângulo de Cobb na escoliose.

Descritores: Escoliose/diagnóstico; Coluna vertebral/anormalidades; Validação de programas de computador; Aplicativos móveis.

\section{RESUMEN}

Objetivo: Validar un nuevo método de medición del ángulo de Cobb para la escoliosis a partir de la aplicación móvil CobbMeter, para facilitar la evaluación y la medición en la práctica clínica. Métodos: Cinco observadores con experiencia mínima de dos años en el área llevaron a cabo mediciones radiográficas del ángulo en 24 radiografías de pacientes con escoliosis idiopática juvenil mediante la aplicación móvil CobbMeter. Los obsenadores realizaron mediciones seriadas en las imágenes con la aplicación, que se repitieron después de un mes. El observador más experimentado del grupo, después de las mediciones realizadas con la aplicación, determinó en cada radiografía el ángulo de Cobb de la manera tradicional. Resultados: La desviación estándar de la media en la comparación de los ángulos medidos por el método electrónico y manual no fue clínicamente significativa. Aunque el $40 \%$ de las mediciones electrónicas están fuera del intervalo de confianza en comparación con las mediciones manuales, esta diferencia fue insignificante en la práctica clínica. Conclusiones: La aplicación CobbMeter es otra alternativa para medir el ángulo de Cobb en la escoliosis.

Descriptores: Escoliosis/diagnóstico; Columna vertebral/anomalías; Validación de programas de computación; Aplicaciones móviles.

\section{INTRODUCTION}

Adolescent idiopathic scoliosis (AIS) ${ }^{1}$ can be defined as lateral deviation of the spine in the frontal plane. In practice, however, it is observed that the deviation is three-dimensional. The patient presents unevenness of the shoulders, and asymmetry of the triangle-cut and rib deformity. AIS mainly affects female adolescents aged between 10 and 18 years, and its etiology is idiopathic. Radiographic evaluations of patients with scoliosis are based on the measurement of the Cobb angle, ${ }^{2}$ which enables analysis of disease progression, and determination of prognosis and treatment.

This calculation is performed by delimiting, on full spine radiographs in the anterior posterior view, the most cranial and more caudal vertebrae in a determined curve. A parallel line is then drawn to the superior plateau of the most cranial vertebral, and another parallel line to the inferior plateau of the most caudal vertebra of the curve. The point where these two lines intersect is the Cobb angle. Traditionally, this measurement is done with a pencil and goniometer.

1. Hospital e Maternidade Celso Pierro (PUC/Campinas), Campinas, SP, Brazil.

Work conducted at the Orthopedics and Traumatology Service of Hospital e Maternidade Celso Pierro (PUC/Campinas), Campinas, SP, Brazil.

Correspondence: Serviço de Ortopedia eTraumatologia do Hospital e Maternidade Celso Pierro (PUC-Campinas) - Av. John Boyd Dunlop, s/n - Jd. Ipaussurama, Campinas, SP, Brazil. 13012-970. rafaelmazzuia@gmail.com 
Adopted as standard by the Scoliosis Research Society since 1966, this is the most widely used method in medical practice, as it is simple and quick to perform, and enables analysis of the degree of the progression and severity of the disease. Kotwick ${ }^{3}$ evaluates that radiographic measurement by the Cobb angle is still the most effective method for patients with scoliosis. Vrtovec et al. ${ }^{4}$ evaluated the curvature in more than one hundred 2D and 3D computerized radiographs, and concluded that many computerized methods were too complex, and were inappropriate for routine clinical evaluation due to their high cost, the difficulty of universal access to the technology, and their immobility, making their use difficult outside hospitals and medical centers.

With the emergence of smartphones, ${ }^{5}$ software programs for cell phones, known as applications, or Apps, have contributed to various fields, assisting health professionals in calculations, measurement of angles, and doses of medications, among other functions. The CobbMeter is an app designed for professionals who have Iphones, and is a program that is sold freely, without the need for prior authorization by the manufacturer. The CobbMeter app was designed to facilitate measurement of the Cobb angle in patients with scoliosis, in order to optimize the clinical practice.

The objective of this work is to validate the Cobb angle calculation method using the CobbMeter Iphone app.

\section{METHODS}

Twenty-four preoperative panoramic teleradiographs in AP (anterior-posterior view) of patients diagnosed with AIS undergoing treatment in the spinal outpatient department of a university hospital were selected. The criteria for inclusion in the trial included orthopedic doctors and orthopedic residents with a minimum of two years and a maximum of ten years of experience. In regard to the radiographs, anterior-posterior panoramic teleradiographs or radiographs of the spine of patients diagnosed with AIS, authorized by the patients through a Voluntary and Informed Consent Form, were included in the evaluation. The work was accepted by the Ethics Committee of our Institution, under number 735.967.

Prior to the data collection, all the radiographs were analyzed by the group, which determined the levels of the curves to be measured. In the case of a patient with a double curve, it was preestablished that the curve with the greatest angle would be measured.

Five medical observers, including three orthopedic doctors who were members of the Sociedade Brasileira de Ortopedia e Traumatologia [Brazilian Society of Orthopedics and Traumatology] (SBOT), specialists in Spinal Surgery of the Sociedade Brasileira de Coluna [Brazilian Spine Society] with up to ten years of training, an orthopedic doctor of the SBOT with specialization in Spine Surgery (R4), and a resident doctor in Orthopedics and Traumatology with at least two years of experience, performed two data collections using the CobbMeter app.

The CobbMeter is able to calculate the Cobb angle on the radiographs using the angle sensor available on the IPhone (microelectromechanical system accelerometer - MEMS). First, the upper part of the app is aligned with the vertebral plateau of the most cranial vertebra of the curve to measured, and the position is validated by clicking on the screen. Next, the lower part of the app is aligned with the lower plateau of the most caudal vertebra of the curve to be measured, and validated again. The Cobb angle is then measured by the sensor on the app, and is shown on the IPhone screen. (Figure 1)

A single IPhone cell phone (model 4S) with the CobbMeter application installed, supplied by the person responsible for the research, was used by all the observers, who were taught in advance how to use the app to correctly measure the angles.

The radiographs were analyzed independently, without any collaboration between the evaluators, all using the app under identical conditions. There was no time limit to take the measurements.

After one month, the same observers evaluated the same

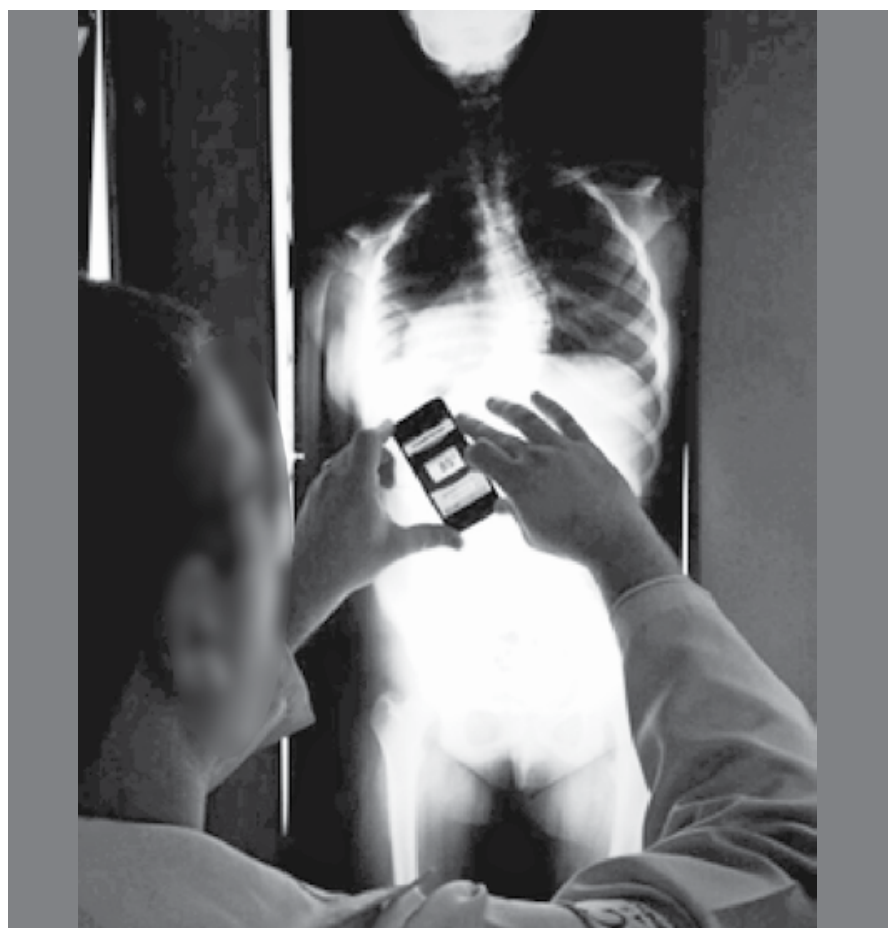

Figure 1. Measurement by the CobbMeter.

radiographs using the app, without any knowledge of the responses signaled previously, or of the data obtained by the other evaluators.

After the measurements using the app, a single measurement of the Cobb angle was performed by the most qualified observer, using the traditional (manual) method.

This transversal study analyzed intra- and inter-observer variations through the Software SPSS 13.0, using the Kappa statistical method, which evaluates agreement between observers by paired analysis, comparing the inter-observer (Po) and intra-observer (Pe) agreement. The values can range from -1.0 (total disagreement) to +10 (total agreement).

\section{RESULTS}

In the intra-observer analyses, we did not identify any significant differences between the first and second measurements using the application, as shown in Table 1.

Comparing the measurements using the app with the manual measurements, we identified significant differences at 95\% confidence in three of the five evaluators. (Tables 2 and 3 ) These results are also shown in Table 4.

The standard deviation between the measurements of the angles performed manually, and the average of the measurements performed by all the observers using the app, is shown in Table 5.

\section{DISCUSSION}

Technological advances have provided many resources that facilitate our routine practices. The growth of ultra-modern cell phones equipped with MEMS capable of performing angle calculations is just one such example. The development of apps that use this app, and their convenience for routine use, makes them an attractive option for daily clinical practice for tasks such as calculating angles in deformities of the vertebral spine. ${ }^{6,7}$ But how reliable are these apps? In this study, we compare the performance of the CobbMeter app with the conventional calculation, in the measurement of Cobb angles in radiographs of patients with scoliosis.

Five experienced observers performed two evaluations of 24 radiographs, one month apart, using the CobbMeter, without any 
Table 1. First and second measurements ( $A$ and $B$ ) with the application in degrees of Cobb angles performed by each observer (1 to 5 ).

\begin{tabular}{c|c|c|c|c|c|c|c|c|c|c}
\hline Observer & \multicolumn{2}{|c|}{} & \multicolumn{2}{|c|}{ 2 } & \multicolumn{2}{|c|}{ 3 } & \multicolumn{2}{|c|}{ 4 } & \multicolumn{2}{|c}{$\mathbf{5}$} \\
\hline Measurement & A & B & A & B & A & B & A & B & A & B \\
\hline Patient 1 & 82 & 84 & 84 & 85 & 83 & 88 & 89 & 91 & 86 & 85 \\
\hline Patient 2 & 34 & 35 & 35 & 38 & 32 & 33 & 31 & 36 & 34 & 31 \\
\hline Patient 3 & 43 & 45 & 45 & 43 & 47 & 48 & 48 & 48 & 41 & 41 \\
\hline Patient 4 & 76 & 76 & 76 & 78 & 83 & 79 & 82 & 83 & 78 & 78 \\
\hline Patient 5 & 80 & 79 & 79 & 85 & 83 & 80 & 87 & 81 & 83 & 85 \\
\hline Patient 6 & 58 & 55 & 55 & 55 & 56 & 57 & 55 & 59 & 54 & 57 \\
\hline Patient 7 & 49 & 48 & 48 & 50 & 48 & 46 & 48 & 51 & 48 & 47 \\
\hline Patient 8 & 50 & 48 & 48 & 50 & 45 & 46 & 45 & 48 & 47 & 47 \\
\hline Patient 9 & 68 & 71 & 69 & 70 & 71 & 71 & 70 & 68 & 70 & 67 \\
\hline Patient 10 & 49 & 51 & 47 & 50 & 49 & 49 & 55 & 49 & 49 & 51 \\
\hline Patient 11 & 52 & 51 & 56 & 57 & 52 & 56 & 54 & 52 & 54 & 58 \\
\hline Patient 12 & 74 & 75 & 75 & 73 & 76 & 74 & 72 & 76 & 71 & 73 \\
\hline Patient 13 & 16 & 17 & 15 & 22 & 18 & 14 & 17 & 14 & 15 & 20 \\
\hline Patient 14 & 18 & 15 & 14 & 13 & 16 & 14 & 14 & 16 & 15 & 15 \\
\hline Patient 15 & 51 & 53 & 56 & 49 & 53 & 52 & 54 & 53 & 53 & 51 \\
\hline Patient 16 & 54 & 56 & 55 & 56 & 57 & 57 & 57 & 60 & 59 & 54 \\
\hline Patient 17 & 44 & 45 & 45 & 50 & 43 & 46 & 46 & 47 & 46 & 45 \\
\hline Patient 18 & 102 & 99 & 98 & 94 & 98 & 102 & 99 & 99 & 99 & 98 \\
\hline Patient 19 & 94 & 93 & 89 & 90 & 91 & 91 & 91 & 90 & 93 & 88 \\
\hline Patient 20 & 50 & 49 & 48 & 47 & 49 & 52 & 52 & 48 & 52 & 50 \\
\hline Patient 21 & 43 & 43 & 40 & 40 & 41 & 40 & 41 & 43 & 40 & 42 \\
\hline Patient 22 & 75 & 75 & 73 & 74 & 74 & 75 & 75 & 73 & 75 & 76 \\
\hline Patient 23 & 36 & 36 & 31 & 34 & 33 & 38 & 33 & 32 & 30 & 30 \\
\hline Patient 24 & 45 & 45 & 45 & 49 & 43 & 43 & 40 & 38 & 43 & 43 \\
\hline Average & 55.96 & 56.00 & 55.25 & 56.33 & 55.88 & 56.29 & 56.46 & 56.46 & 55.63 & 55.50 \\
\hline SD & 21.66 & 21.56 & 21.65 & 20.99 & 22.09 & 22.49 & 22.75 & 22.50 & 22.47 & 21.87 \\
\hline & & & & & & &
\end{tabular}

Table 2. Measurements performed with the app in which $1 \mathrm{~A}$ corresponds to observer 1 performing the first measurement $(A), 1 B$ being her second measurement, and so on (2A, 2B, 3A, 3B, 4A, 4B, 5A and 5B) and the values for the manual measurement $(\mathrm{M})$.

\begin{tabular}{c|c|c|c|c|c|c|c|c|c|c|c}
\hline & 1A & 1B & 2A & 2B & 3A & 3B & 4A & 4B & 5A & 5B & M \\
\hline Patient 1 & 82 & 84 & 84 & 85 & 83 & 88 & 89 & 91 & 86 & 85 & 94 \\
\hline Patient 2 & 34 & 35 & 35 & 38 & 32 & 33 & 31 & 36 & 34 & 31 & 33 \\
\hline Patient 3 & 43 & 45 & 45 & 43 & 47 & 48 & 48 & 48 & 41 & 41 & 42 \\
\hline Patient 4 & 76 & 76 & 76 & 78 & 83 & 79 & 82 & 83 & 78 & 78 & 82 \\
\hline Patient 5 & 80 & 79 & 79 & 85 & 83 & 80 & 87 & 81 & 83 & 85 & 88 \\
\hline Patient 6 & 58 & 55 & 55 & 55 & 56 & 57 & 55 & 59 & 54 & 57 & 55 \\
\hline Patient 7 & 49 & 48 & 48 & 50 & 48 & 46 & 48 & 51 & 48 & 47 & 50 \\
\hline Patient 8 & 50 & 48 & 48 & 50 & 45 & 46 & 45 & 48 & 47 & 47 & 49 \\
\hline Patient 9 & 68 & 71 & 69 & 70 & 71 & 71 & 70 & 68 & 70 & 67 & 73 \\
\hline Patient 10 & 49 & 51 & 47 & 50 & 49 & 49 & 55 & 49 & 49 & 51 & 50 \\
\hline Patient 11 & 52 & 51 & 56 & 57 & 52 & 56 & 54 & 52 & 54 & 58 & 56 \\
\hline Patient 12 & 74 & 75 & 75 & 73 & 76 & 74 & 72 & 76 & 71 & 73 & 75 \\
\hline Patient 13 & 16 & 17 & 15 & 22 & 18 & 14 & 17 & 14 & 15 & 20 & 18 \\
\hline Patient 14 & 18 & 15 & 14 & 13 & 16 & 14 & 14 & 16 & 15 & 15 & 14 \\
\hline Patient 15 & 51 & 53 & 56 & 49 & 53 & 52 & 54 & 53 & 53 & 51 & 52 \\
\hline Patient 16 & 54 & 56 & 55 & 56 & 57 & 57 & 57 & 60 & 59 & 54 & 58 \\
\hline Patient 17 & 44 & 45 & 45 & 50 & 43 & 46 & 46 & 47 & 46 & 45 & 50 \\
\hline Patient 18 & 102 & 99 & 98 & 94 & 98 & 102 & 99 & 99 & 99 & 98 & 96 \\
\hline Patient 19 & 94 & 93 & 89 & 90 & 91 & 91 & 91 & 90 & 93 & 88 & 92 \\
\hline Patient 20 & 50 & 49 & 48 & 47 & 49 & 52 & 52 & 48 & 52 & 50 & 50 \\
\hline Patient 21 & 43 & 43 & 40 & 40 & 41 & 40 & 41 & 43 & 40 & 42 & 44 \\
\hline Patient 22 & 75 & 75 & 73 & 74 & 74 & 75 & 75 & 73 & 75 & 76 & 76 \\
\hline Patient 23 & 36 & 36 & 31 & 34 & 33 & 38 & 33 & 32 & 30 & 30 & 32 \\
\hline Patient 24 & 45 & 45 & 45 & 49 & 43 & 43 & 40 & 38 & 43 & 43 & 46 \\
\hline Average & 55.96 & 56.00 & 55.25 & 56.33 & 55.88 & 56.29 & 56.46 & 56.46 & 55.63 & 55.50 & 57.29 \\
\hline SD & 21.66 & 21.56 & 21.65 & 20.99 & 22.09 & 22.49 & 22.75 & 22.50 & 22.47 & 21.87 & 22.86 \\
\hline
\end{tabular}

Table 3. Results of the paired tests between the two measurements with the app performed by each observer ( $1 \mathrm{~A}$ and $\mathrm{B}, 2 \mathrm{~A}$ and $\mathrm{B}, 3 \mathrm{~A}$ and $\mathrm{B}, 4 \mathrm{~A}$ and $B, 5 \mathrm{~A}$ and $\mathrm{B})$.

\begin{tabular}{c|c|c}
\hline Measurement & p-value & Significant (95\% confidence) \\
\hline $1(A$ and $B)$ & 0.907 & No \\
\hline $2(A$ and $B)$ & 0.098 & No \\
\hline $3(A$ and $B)$ & 0.441 & No \\
\hline $4(A$ and $B)$ & 1.000 & No \\
\hline $5(A$ and $B)$ & 0.811 & No \\
\hline
\end{tabular}

Table 4. Results of the paired tests between each measurement performed with the app for each observer ( $1 \mathrm{~A}$ and $\mathrm{B}, 2 \mathrm{~A}$ and $\mathrm{B}, 3 \mathrm{~A}$ and $\mathrm{B}, 4 \mathrm{~A}$ and $\mathrm{B}$, $5 \mathrm{~A}$ and $\mathrm{B})$ compared with the manual measurements $(\mathrm{M})$.

\begin{tabular}{c|c|c}
\hline Measurement & p-value & Significant (95\% confidence) \\
\hline $1 A-M$ & 0.126 & No \\
\hline $2 A-M$ & 0.007 & Yes \\
\hline $3 A-M$ & 0.047 & Yes \\
\hline $4 A-M$ & 0.179 & No \\
\hline $5 A-M$ & 0.004 & Yes \\
\hline $1 B-M$ & 0.086 & No \\
\hline $2 B-M$ & 0.129 & No \\
\hline $3 B-M$ & 0.182 & No \\
\hline $4 B-M$ & 0.248 & No \\
\hline $5 B-M$ & 0.005 & Yes
\end{tabular}

Table 5. Standard deviation Cobb (in degrees) between the manual measurements and the average of the measurements of all the observers with the app in each patient.

\begin{tabular}{c|c|c|c}
\hline & Cobb Manual & Average Cobb APP & Standard deviation Cobb \\
\hline Patient 1 & 94 & 85.7 & 2.83 \\
\hline Patient 2 & 33 & 33.9 & 2.37 \\
\hline Patient 3 & 42 & 44.9 & 2.81 \\
\hline Patient 4 & 82 & 78.9 & 2.81 \\
\hline Patient 5 & 88 & 82.2 & 2.82 \\
\hline Patient 6 & 55 & 56.1 & 1.60 \\
\hline Patient 7 & 50 & 48.3 & 1.42 \\
\hline Patient 8 & 49 & 47.4 & 1.78 \\
\hline Patient 9 & 73 & 69.5 & 1.43 \\
\hline Patient 10 & 50 & 49.9 & 2.13 \\
\hline Patient 11 & 56 & 54.2 & 2.44 \\
\hline Patient 12 & 75 & 73.9 & 1.66 \\
\hline Patient 13 & 18 & 16.8 & 2.62 \\
\hline Patient 14 & 14 & 15.0 & 1.41 \\
\hline Patient 15 & 52 & 52.5 & 1.90 \\
\hline Patient 16 & 58 & 56.5 & 1.96 \\
\hline Patient 17 & 50 & 45.7 & 1.89 \\
\hline Patient 18 & 96 & 98.8 & 2.25 \\
\hline Patient 19 & 92 & 91.0 & 1.89 \\
\hline Patient 20 & 50 & 49.7 & 1.83 \\
\hline Patient 21 & 44 & 41.3 & 1.34 \\
\hline Patient 22 & 76 & 74.5 & 0.97 \\
\hline Patient 23 & 32 & 33.3 & 2.71 \\
\hline Patient 24 & 46 & 43.4 & 2.99 \\
\hline & & Average SD Cobb: & 2.08 \\
\hline
\end{tabular}

identification being shown in the exams that could compromise the measurement. The radiographs were then measured with a pencil and goniometer, by the most experienced evaluator of the group, who determined the Cobb angles to be interpreted as standard. These measurements were compiled and analyzed by the software SPSS 13.0, using the Kappa statistical method. The inter- and intra-observer measurements using the app were then compared with the standard manual measurements.

In this study, the differences between two intra-observer measurements using the CobbMeter app were not significant. However, when the electronic measurements were compared with the manual 
measurements, only the evaluations performed by two examiners showed 95\% confidence in the paired test (Tables 1 to 4).

This indicates that the electronic measurement using the CobbMeter app was statistically reliable for all the evaluators. The deviations found do not, from a clinical point of view, hinder the diagnosis or the establishment of a prognosis and definition of the treatment in these cases. Even taking into account different examiners, the app is still accurate for the measurement of the Cobb angles in the radiographs.

However, when we compare the measurements of the CobbMeter with the manual measurement, $60 \%$ of them presented at least $95 \%$ confidence. It is therefore concluded that $40 \%$ of the measurements are outside the confidence interval established in the statistical analysis.

\section{CONCLUSIONS}

In practice, $2.08^{\circ}$ of the difference, whether upwards or downwards (4.16 in absolute terms), in the measurement of a scoliosis curve is not of a level of significance that would cause errors of interpretation for the diagnosis, establishment of prognosis or definition of treatment. These deviations also found intra- and inter-observers in the routine manual calculation. Thus, the use of the CobbMeter app for calculating the Cobb angle on the radiographs adolescent idiopathic scoliosis used in this study is considered safe, and applicable for clinical practice.

All authors declare no potential conflict of interest concerning this article.

\section{REFERENCES}

1. Hebert SK, Barros Filho EP, Xavier R, Pardini Junior AG. Ortopedia e traumatologia: princípios e práticas. $4^{\mathrm{a}}$ ed. Porto Alegre: Artmed; 2009.

2. Cobb JR. Outline for the study of scoliosis. Instr Course Lect. 1948;5:261-75.

3. Kotwicki T. Evaluation of scoliosis today: examination, X-rays and beyond. Disabil Rehabil. 2008:30(10):742-51.

4. Vrtovec T, Pernus F, Likar B. A review of methods for quantitative evaluation of spinal curvature. Eur Spine J. 2009;18(5):593-607.
5. Shaw M, Adam CJ, Izatt MT, Licina P, Askin GN. Use of the iPhone for Cobb angle measurement in scoliosis. Eur Spine J. 2012:21(6):1062-8.

6. Langensiepen S, Semler O, Sobottke R, Fricke O, Franklin J, Schönau E, et al. Measuring procedures to determine the Cobb angle in idiopathic scoliosis: a systematic review. Eur Spine J. 2013;22(11):2360-71.

7. Qiao J, Liu Z, Xu L, Wu T, Zheng X, Zhu Z, et al. Reliability analysis of a smartphone-aided measurement method for the Cobb angle of scoliosis. J Spinal Disord Tech. 2012;25(4):E88-92. 